\title{
Association of $+331 \mathrm{G} / \mathrm{A}$ PgR Polymorphism with Susceptibility to Female Reproductive Cancer: Evidence from a Meta-Analysis
}

\author{
Sanjib Chaudhary ${ }^{19}$, Aditya K. Panda ${ }^{29}$, Dipti Ranjan Mishra ${ }^{1}$, Sandip K. Mishra ${ }^{1 *}$ \\ 1 Cancer Biology Lab, Department of Gene Function and Regulation, Institute of Life Sciences, Bhubaneswar, Odisha, India, 2 Department of Infectious Disease Biology,
} Institute of Life Sciences, Bhubaneswar, Odisha, India

\begin{abstract}
The progesterone receptor $(\mathrm{PgR})$, a sex steroid hormone receptor that binds progesterone is critical for normal breast development. The PgR (+331G/A, rs 10895068) promoter polymorphism is associated with cancer risk possibly by altering the expression of progesterone receptor $B$ isoform. Previous studies have provided inconsistent results. To validate the association between the $\mathrm{PgR}+331 \mathrm{G} / \mathrm{A}$ polymorphism and female reproductive cancer risk (breast, endometrial and ovarian cancer), we performed a meta-analysis of 19 studies (19,978 cases and 24,525 controls) by using the CMA Version 2 software. Odds ratios (ORs) and $95 \%$ confidence intervals (Cls) were used to assess the strength of the associations. The overall results indicated that the variant allele and genotypes were associated with a mild increase in overall female reproductive cancer risk (A vs. G: $\mathrm{OR}=1.063,95 \% \mathrm{Cl}=1.001-1.129 ; \mathrm{AA}+\mathrm{AG}$ vs. GG: $\mathrm{OR}=1.067,95 \% \mathrm{Cl}=1.002-1.136$ ). The results suggest that the $\mathrm{PgR}+331 \mathrm{G} / \mathrm{A}$ polymorphism might be associated with an increased female reproductive cancer risk.
\end{abstract}

Citation: Chaudhary S, Panda AK, Mishra DR, Mishra SK (2013) Association of +331G/A PgR Polymorphism with Susceptibility to Female Reproductive Cancer: Evidence from a Meta-Analysis. PLoS ONE 8(1): e53308. doi:10.1371/journal.pone.0053308

Editor: Amanda Ewart Toland, Ohio State University Medical Center, United States of America

Received June 25, 2012; Accepted November 27, 2012; Published January 22, 2013

Copyright: (c) 2013 Chaudhary et al. This is an open-access article distributed under the terms of the Creative Commons Attribution License, which permits unrestricted use, distribution, and reproduction in any medium, provided the original author and source are credited.

Funding: SC, AKP and DRM were supported by Department of Biotechnology, Council of Scientific and Industrial Research and Indian Council of Medical Research respectively. This work was supported by intramural grant of Institute of Life Sciences, Department of Biotechnology, Government of India. The funders had no role in study design, data collection and analysis, decision to publish, or preparation of the manuscript.

Competing Interests: The authors declare that they have no conflict of interest.

* E-mail: sandipkmishra@hotmail.com

9 These authors contributed equally to this work.

\section{Introduction}

It is now well established that cancer is a multifactorial disease with an orchestrated relationship between genetic and environmental factors $[1,2]$. Despite intense study, the number of cancer cases continues to dramatically increase globally. According to American Cancer Society in 2012, more than 500,000 Americans are expected to die from cancer with more than 1500 deaths per day [3].

The progesterone receptor $(\mathrm{PgR})$ is a member of a large ligandactivated nuclear receptor family characterised by a central DNA binding domain, a carboxyl-terminal ligand binding domain and multiple activation (AF) and inhibitory (IF) functional elements. The PgR, which is located on chromosome $1 \mathrm{lq} 22$, and the oestrogen receptor (ER) have diverse reproductive functions associated with the establishment and maintenance of pregnancy, alveolar development and mammary epithelial development $[4,5,6]$. Progesterone, a steroid hormone, binds to the PgR, causing dimerization and thereby activating its target genes to transcribe through its response elements (PRE). The binding and activation are responsible for the mammary epithelial proliferation [7]. The PgR gene is transcribed by two alternative promoters that translate into two isoforms, progesterone receptor A (PgRA) and progesterone receptor $\mathrm{B}(\mathrm{PgRB})$ through which the PgR mediates its physiological functions [6]. The ratio of the expression of the two isoforms is important for the normal physiological function of progesterone signalling, which gets abrogated in cancer [8]. Both isoforms are identical except for the absence of 164 amino acids in $\mathrm{N}$-terminal end of PgRA, which are present in the PgRB. This makes PgRB unique from PgRA because of the presence of AF-3 apart from AF-1 and AF-2, which are normally present in PgRA [9]. Six variable sites, four polymorphism and five common haplotypes have been detected in the PgR gene [10]. The most widely studied polymorphism in the promoter region of the PgR gene is the $\mathrm{G}$ to $\mathrm{A}$ substitution at position +331 (progesterone receptor, +331 G/A, rs10895068, +331 from ATG start codon). Interestingly, a unique GATA-5 binding site that is adjacent to the +331G/A PgR polymorphism has been found that leads to increased transcriptional activity of $\mathrm{PgRB}$ isoforms. In vitro overexpression of GATA-5 with hPgR luciferase construct showed greater transcriptional activity with +331AA than with +331GG included in the luciferase construct thereby contributing to breast tumorigenesis [11].

Recently, many studies have investigated the role of the PgR $+331 \mathrm{G} / \mathrm{A}$ polymorphism in the etiology of various types of cancer, i.e., breast, ovary and endometrial cancer. However, the results of these studies remain inconclusive. To clarify the role of $+331 \mathrm{G} / \mathrm{A}$ PgR polymorphism in female reproductive cancers, we performed a meta-analysis of all of the eligible case-control studies to derive overall cancer risk associated this polymorphism (Figure S1). 


\section{Materials and Methods}

\section{Identification and eligibility of relevant study}

Recent publications were identified through a literature search using the keywords "Progesterone receptor polymorphism," "PgR polymorphism" or "PR polymorphism", and "+331G $>$ A", or "+331G/A" and "cancer" in Pubmed and cross-references were checked that were not available in Pubmed or Science Direct (published before July 2012). Only those articles written in English were selected for the study. The following criteria were used for inclusion of identified articles for our meta-analysis: (a) evaluation of +331 G/A and cancer risk, (b) case-control study or cohort design and (c) studies that contained available genotype frequencies. The major reason of exclusion of some investigations was the absence of usable data reported in those studies. Finally, the data were extracted from 19 case-control studies totalling to 19,978 cases and 24,525 controls for $+331 \mathrm{G} / \mathrm{A}$ PgR polymorphism.

\section{Data extraction}

Two investigators (SC and DRM) independently extracted all of the data and jointly reached the consensus for all of the articles that were included in the study. Disagreement between the authors was resolved after discussion amongst the authors. The following information was sought from each article: first author's name, year of publication, source of control, country, ethnicity and numbers of cases and controls, genotype frequencies and allele frequencies for each case and control.

\section{Meta-analysis}

The statistical analysis for the current meta-analysis study was performed by using the comprehensive meta-analysis (CMA) V2 software (Biostat, USA). Meta-analysis is a powerful tool which combines results of independent similar studies and derive a definitive conclusion [12]. CMA V2 has several advantages over other software available for computing meta-analyses (http:// www.meta-analysis.com/pages/comparisons.html). The strength of the association between the PgR $+331 \mathrm{G} / \mathrm{A}$ polymorphism and risk of cancer was measured by odd ratios (ORs) with 95\% confidence intervals (CIs). We examined the association between the allele $\mathrm{A}$ of the $\mathrm{PgR}+331 \mathrm{G} / \mathrm{A}$ polymorphism and cancer risk, and made comparisons with the dominant genetic model $(\mathrm{AA}+\mathrm{AG}$ vs. GG). A recessive genetic model was not performed as the data were not available for the homozygous mutant (AA) in the studied cases. The heterogeneity assumption was evaluated with an $\mathrm{I}^{2}$ based Cochran's $Q$ statistic test. A significant $p$ value $(<0.10)$ was used to indicate heterogeneity among studies, and the combined OR was calculated by using a random effect model [13]. In contrast, a fixed effect model [14] was used for the calculation of the combined OR for homogeneity among the studies. In addition, the $\mathrm{I}^{2}$ statistic was used to quantify inter-study variability. This statistic ranged from 0 to $100 \%$, where a value of $0 \%$ indicated no observed heterogeneity, and as the values increased the degree of heterogeneity increased (cut-off points include: $\mathrm{I}^{2}=0-25 \%$, no heterogeneity; $\mathrm{I}^{2}=25-50 \%$, moderate heterogeneity; $\mathrm{I}^{2}=50-75 \%$, large heterogeneity; $\mathrm{I}^{2}=75-100 \%$, extreme heterogeneity) [15]. The funnel plot was employed to examine the publication bias. Egger's regression analysis was used for reevaluation of publication bias, and a $\mathrm{P}$ value less than 0.10 was considered to be significant. Funnel plots and Egger's linear regression tests were used to provide a diagnosis of the potential publication bias.

\section{Results}

\section{Study characteristics}

For the association between PgR $+331 \mathrm{G} / \mathrm{A}$ polymorphism and cancer susceptibility, articles were retrieved based on the established search criteria. Nineteen studies met the inclusion criteria, the characteristics of which are reported in Table 1. Of these 19 studies, 10 were breast cancer (BC) studies in which all of the patients were of European ethnicity [11,16-24]; six were ovarian cancer $(\mathrm{OC})$ studies that only included patients of European origin $[10,17,20,25,26,27]$ and three studies were endometrial cancer (EC) studies, which enrolled patients of different ethnic groups [28,29,30].

\section{Publication bias}

Begg's Funnel plot and Egger's test was conducted to assess whether there was any publication bias in the studies included in our meta-analysis. The shape of the funnel did not elucidate any obvious asymmetry in all of the comparison models. Thereafter, Egger's test was used to provide statistical evidence of the funnel plot symmetry and did not show any publication bias (Table 2).

\section{Heterogeneity test}

Q-test and $\mathrm{I}^{2}$ statistics were used to test for heterogeneity among the studies. No heterogeneity was observed in either allele (A vs. G) as well as the dominant genotype model for overall cancer, which was included for the analysis (Overall allele, A vs. G: $Q=31.08$, $\mathrm{P}_{\text {heterogeneity }}=0.186, \mathrm{I}^{2}=19.58$; Overall dominant model, AA+GG vs. GG: $Q=25.76, P_{\text {heterogeneity }}=0.11, \mathrm{I}^{2}=25.76$ ).

\section{Meta-analysis result}

Our meta-analysis identified an evident mild association between PgR (+331G/A) polymorphism and an increased cancer risk. Compared with the wild-type $\mathrm{G}$ allele, the overall variant $\mathrm{A}$ allele was associated with a mild increased cancer risk $(\mathrm{OR}=1.063,95 \% \mathrm{CI}=1.001-1.129, \mathrm{p}=0.048)$ [Figure $1(\mathrm{I})] . \mathrm{In}$ addition, the dominant model (AA+AG vs. GG) too showed a modest association between the polymorphism and an increased cancer risk $(\mathrm{OR}=1.067,95 \% \mathrm{CI}=1.002-1.136, \quad \mathrm{p}=0.043)$ [Figure 1 (II)].

\section{Discussion}

Genetic epidemiological studies have suggested the relationship between different SNPs and disease. However, robust statistical powers with genotype-phenotype investigation are essential to detect the mild, moderate or strong association with the disease. The progesterone hormone mediates its physiological function through the PgR, a steroid receptor of class I nuclear receptor super-family. Two different isoforms of PgR (PgRA and PgRB), which are transcribed from two different promoters of the same gene $[31,32]$ are co-expressed in equal levels in normal mammary epithelial [33], ovarian [34] and endometrial cells [35]. The relative expression of this two isoform is altered in malignant transformation. The $\mathrm{PgR}+331$ $\mathrm{G} / \mathrm{A}$ polymorphism in the promoter results in the introduction of a TATA box that selectively enhances the production of the PgRB isoform, causing an altered PgRA: PgRB protein ratio [36]. The $\mathrm{PgR}+331 \mathrm{G} / \mathrm{A}$ promoter polymorphism has been extensively studied because of its relationship in different cancers such as breast, endometrial and ovarian cancer. However, the results from these studies were ambiguous. Apart from the $\mathrm{PgR}+331 \mathrm{G} / \mathrm{A}$ polymorphism, there are additional 


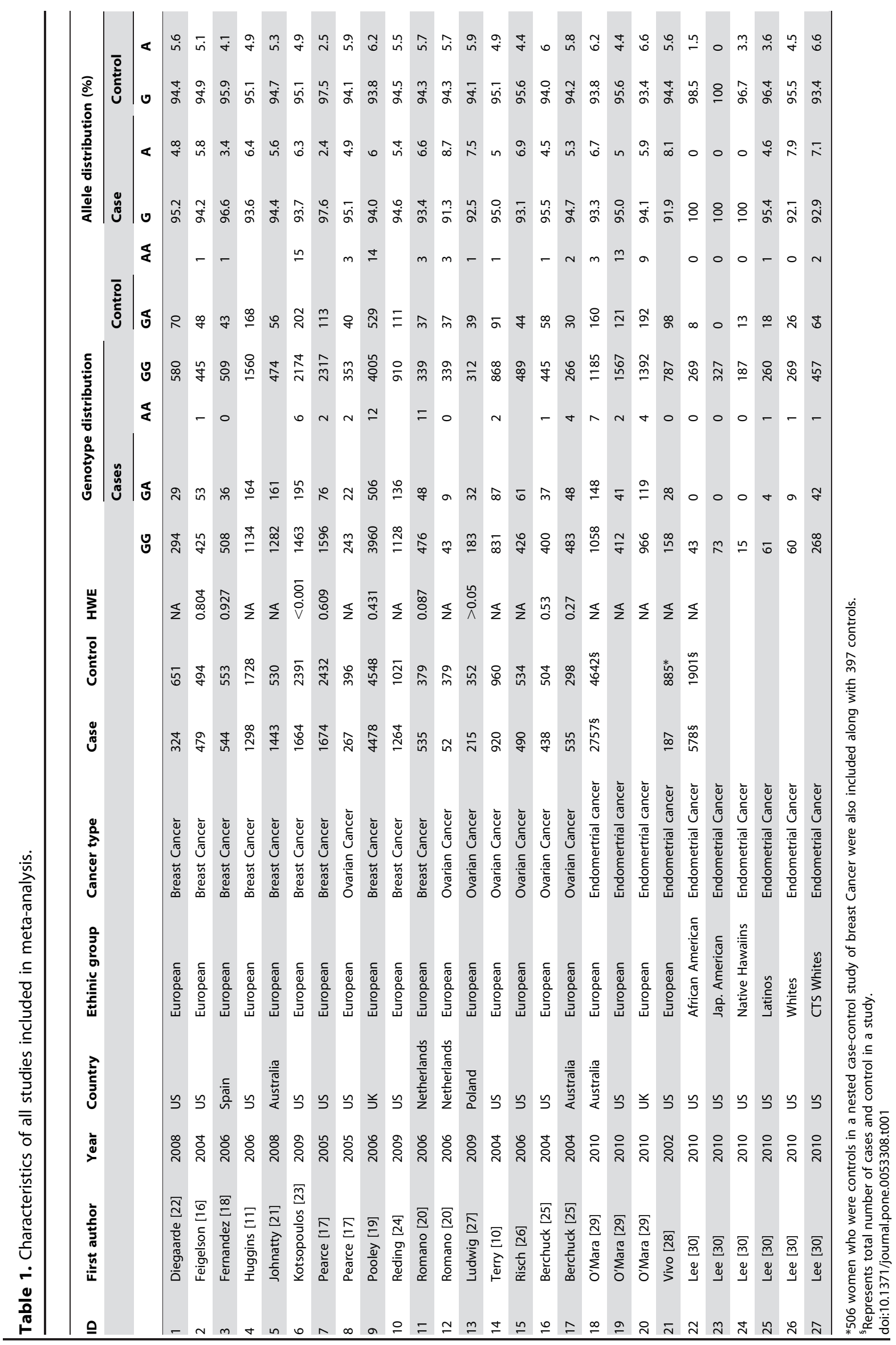


Table 2. Statistics to test publication bias and heterogeneity in meta-analysis.

\begin{tabular}{|c|c|c|c|c|c|c|c|c|c|c|}
\hline \multirow{2}{*}{ SNP } & \multirow{2}{*}{ Study } & \multicolumn{2}{|c|}{ Sample Size } & \multirow[b]{2}{*}{ intercept } & \multirow{2}{*}{$\begin{array}{l}\text { Egger's regression Analysis } \\
95 \% \mathrm{Cl}\end{array}$} & \multirow[b]{2}{*}{ p value } & \multirow[b]{2}{*}{$Q$ value } & \multicolumn{3}{|c|}{ Heterogeneity analysis } \\
\hline & & Case & Control & & & & & $\mathbf{P h}$ & $12(\%)$ & Model \\
\hline A vs. G & Overall & 19978 & 24525 & 0.18 & -0.74 to 1.12 & 0.68 & 31.08 & 0.186 & 19.58 & Fixed \\
\hline$A A+A G$ vs. GG & Overall & 19978 & 24525 & 0.1 & -0.86 to 1.08 & 0.81 & 33.67 & 0.18 & 25.76 & Fixed \\
\hline
\end{tabular}

doi:10.1371/journal.pone.0053308.t002

polymorphisms such as +44C/T, S344T, G393G, V600L, $\mathrm{H} 770 \mathrm{H}$ and Alulns allele [37]. We evaluated the $+331 \mathrm{G} / \mathrm{A}$ PgR promoter polymorphism for two reasons: (1) its association with many cancers like endometrial, ovarian and breast cancer, although there are conflicting observations and (2) the functional attribute of $+331 \mathrm{G} / \mathrm{A}$ PgR has been delineated and has been found to play an important role in hormone related cancer.

In previous published pooled studies, Yang and colleagues have reported an association between $\mathrm{PgR}+331 \mathrm{G} / \mathrm{A}$ variant and breast cancer risk [38]. However, the other meta-analysis reviewed an additional 4 studies and did not find this association [39]. On the basis of availability of more studies on PgR +331 G/A polymorphism and female hormone dependent cancer, we did a meta-analysis to determine conclusively whether an association exists between them. We detected a mild association between PgR +331 G/A polymorphism with overall female cancer risk. As all the studies involved women of only Caucasian origin, we did not perform any subgroup analysis by ethnicity. The prevalence of a minor allele $\mathrm{A}$ is restricted to only the European population (5$10 \%)$ and is rare in women of African, Asian and Middle Eastern descent which might be the reason for mild association even if the included studies are high. [40]. The non-detection of association between the $\mathrm{PgR}+331 \mathrm{G} / \mathrm{A}$ polymorphism and breast cancer was consistent with the previous study [39].

A genome-wide association studies (GWAS) have been carried out for various cancers (breast, prostate, colorectal, and lung) and several susceptible alleles have been identified [41]. None of the GWAS have identified the $+331 \mathrm{G} / \mathrm{A} \mathrm{PgR}$ polymorphism as a risk factor for cancer predisposition despite this functional SNP has been established. In contrast, our meta-analysis results revealed an association of the $\mathrm{PgR}$ (+331 G/A) polymorphism with a susceptibility to cancer. Corroborating with current study, discrepancies between the GWAS and candidate gene association studies (GG) have been reported for different disease $[42,43,44,45]$. CG studies tend to have higher statistical power than the power in GWAS [46].

The progesterone hormone exerts its physiologic effect exclusively through the presence of the $\mathrm{PgR}$ as shown in mouse models $[47,48]$. The PgR isoforms, PgRA and PgRB, display different transactivation properties based on the cell type and target promoter [49]. PgRB functions as a strong transcriptional activator of the PgR-dependent promoters in PgRA-inactive cell types, but the agonist-bound PgRA under this condition can repress the $\operatorname{PgRB}$ transcriptional activity and other steroid receptors like ER $\alpha$ [50]. Progesterone acts as an antagonist of oestrogen (E2)-induced cell proliferation of uterine epithelium through PgRA [48]. Treating PRAKO ${ }^{-/-}$mice (deficient in PgRA) with E2 and progesterone resulted in a progesteronedependent cell proliferation, which was not detected in E2 and progesterone-treated wild-type or PRAKO mice, suggesting that PgRB has a role in uterine endometrium proliferation. Further- more, the PgRB isoform could also elicit normal proliferation and differentiation as observed in $\mathrm{PRAKO}^{-/-}$mammary epithelium through progesterone. During endometriosis, only the PgRA isoform is expressed and the absence of PgRB is suggested due to the inappropriate cycling of the endometrial gland [25]; however PgRA expression in normal cycling is predominant during the proliferative phase, which shifts towards PgRB expression during the early secretary phase [33]. The upregulation and proliferative nature of the PgRB isoform in the carriers of the $+331 \mathrm{~A}$ allele may result in different types of cancer [25]. With respect to this biological postulation, the $+331 \mathrm{G} / \mathrm{A}$ PgR may modulate cancer risk. However, the association of this polymorphism with overall cancer risk was mild $(\mathrm{OR}=1.063, \mathrm{p}=0.048)$. It is important to note that expression of the $\mathrm{PgR}$ is associated with better disease-free survival [51]. An alteration in the ratio of the expression of the $\mathrm{PgR}$ isoforms precedes changes that may lead to endometrial carcinoma [52]. The increase in PgRB expression due to polymorphism in promoter leads to changes in the isoform ratio and is associated with an increased risk of developing endometrial cancer [53]. Additionally, a case-control study of endometrial cancer with the $+331 \mathrm{G} / \mathrm{A}$ PgR polymorphism and PgR expression predicted that the recurrence risk and clinical response to progesterone therapy was six times more likely in women with $\mathrm{PR}(+)$ than with $\mathrm{PR}(-)$ tumors. Progesterone therapy is effective against the developed endometrial cancer, which is dependent on oestrogen-mediated proliferation. Also, $\mathrm{PR}(+)$ endometrial cancer was an independent prognostic factor in disease-free survival [54]. The finding that PgRB could contribute to cell proliferation may provide clinical implications for hormonal management of endometrial and mammalian epithelium by rectifying relative expression of the PgRA: PgRB isoform, which is essential for appropriate reproductive tissue responses. Isoform-specific modulators like progestin, which could differentiate between PgRA and PgRB isoform, may also be of clinical value.

Although earlier reports on the association of PgR (+331G/A) polymorphism and cancer are inconsistent, the current metaanalysis has provided a definitive conclusion. Inconsistencies among the CG association studies could be attributed to small sample sizes, improper clinical categorisation and the inclusion of different ethnicities.

\section{Conclusion}

A mild association between $\operatorname{PgR}+331 \mathrm{G} / \mathrm{A}$ polymorphism and female reproductive cancer risk was detected. As the eligible case-control studies cannot provide a casual relationship, large and well-designed genotype-phenotype studies on different cancer are necessary to derive a definitive role of this SNP with cancer. 


\section{(I) Overall Allele A vs. G}

Study name

Vivo et al. 2002 (b)

Feigelson et al. 2004 (a)

Terry et al. 2004 (c)

Berchuck et al. 2004 (US) (c)

Berchuck et al. 2004 (Australia) (c)

Pearce et al. 2005 (a)

Pearce et al. 2005 (c)

Fernandez et al. 2006 (a)

Huggins et al. 2006 (a)

Pooley et al. 2006 (a)

Romano et al. 2006 (a)

Romano et al. 2006 (c)

Risch et al. 2006 (c)

Johnatty et al. 2008 (a)

Diegaarde et al. 2008 (a)

Kotsopoulos et al. 2009 (a)

Reding et al. 2009 (a)

Ludwig et al. 2009 (c)

O'Mara et al. 2010 (Australia) (b)

O'Mara et al. 2010 (US) (b)

O'Mara et al. 2010 (UK) (b)

Lee et al. 2010 (African American) (b)

Lee et al. 2010 (Hawaiins) (b)

Lee et al. 2010 (Latinos) (b)

Lee et al. 2010 (Whites) (b)

Lee et al. 2010 (CTS Whites) (b)

Combined

Statistics for each study

$\begin{array}{cccrr}\begin{array}{c}\text { Odds } \\ \text { ratio }\end{array} & \begin{array}{c}\text { Lower } \\ \text { limit }\end{array} & \begin{array}{c}\text { Upper } \\ \text { limit }\end{array} & \text { Z-Value } & \text { p-Value } \\ 1.389 & 0.898 & 2.147 & 1.477 & 0.140 \\ 1.143 & 0.771 & 1.694 & 0.664 & 0.507 \\ 1.022 & 0.760 & 1.375 & 0.145 & 0.885 \\ 0.736 & 0.487 & 1.113 & -1.451 & 0.147 \\ 0.913 & 0.589 & 1.415 & -0.408 & 0.684 \\ 1.028 & 0.770 & 1.374 & 0.189 & 0.850 \\ 0.830 & 0.506 & 1.360 & -0.739 & 0.460 \\ 0.807 & 0.516 & 1.261 & -0.942 & 0.346 \\ 1.320 & 1.058 & 1.647 & 2.456 & 0.014 \\ 0.964 & 0.853 & 1.090 & -0.581 & 0.561 \\ 1.164 & 0.787 & 1.722 & 0.760 & 0.447 \\ 1.575 & 0.744 & 3.334 & 1.188 & 0.235 \\ 1.552 & 1.043 & 2.310 & 2.165 & 0.030 \\ 1.059 & 0.775 & 1.448 & 0.361 & 0.718 \\ 0.826 & 0.530 & 1.287 & -0.845 & 0.398 \\ 1.301 & 1.073 & 1.577 & 2.672 & 0.008 \\ 0.989 & 0.764 & 1.280 & -0.083 & 0.934 \\ 1.300 & 0.806 & 2.098 & 1.075 & 0.283 \\ 1.091 & 0.872 & 1.364 & 0.759 & 0.448 \\ 1.152 & 0.818 & 1.622 & 0.810 & 0.418 \\ 0.878 & 0.699 & 1.107 & -1.726 & 0.260 \\ 0.372 & 0.021 & 6.497 & -0.678 & 0.498 \\ 0.471 & 0.027 & 8.107 & -0.519 & 0.604 \\ 1.281 & 0.504 & 3.255 & 0.520 & 0.603 \\ 1.850 & 0.891 & 3.840 & 1.650 & 0.099 \\ 1.095 & 0.739 & 1.622 & 0.452 & 0.651 \\ 1.063 & 1.001 & 1.129 & 1.980 & 0.048\end{array}$

\section{(II) Overall Dominant AA+AG vs. GG}

\section{Study name}

Vivo et al. 2002 (b)

Feigelson et al. 2004 (a)

Terry et al. 2004 (c)

Berchuck et al. 2004 (US) (c)

Berchuck et al. 2004 (Australia) (c)

Pearce et al. 2005 (a)

Pearce et al. 2005 (c)

Fernandez et al. 2006 (a)

Huggins et al. 2006 (a)

Pooley et al. 2006 (a)

Romano et al. 2006 (a)

Romano et al. 2006 (c)

Risch et al. 2006 (c)

Johnatty et al. 2008 (a)

Diegaarde et al. 2008 (a)

Kotsopoulos et al. 2009 (a)

Reding et al. 2009 (a)

Ludwig et al. 2009 (c)

O'Mara et al. 2010 (Australia) (b)

O'Mara et al. 2010 (US) (b)

O'Mara et al. 2010 (UK) (b)

Lee et al. 2010 (African American) (b)

Lee et al. 2010 (Hawaiins) (b)

Lee et al. 2010 (Latinos) (b)

Lee et al. 2010 (Whites) (b)

Lee et al. 2010 (CTS Whites) (b)

Combined
Statistics for each study

\section{Odds Lower Upper}

ratio limit limit Z-Value $p$-Value

$\begin{array}{lllll}1.423 & 0.904 & 2.240 & 1.525 & 0.127\end{array}$

$\begin{array}{lllll}1.154 & 0.767 & 1.737 & 0.686 & 0.493\end{array}$

$\begin{array}{lllll}1.010 & 0.744 & 1.373 & 0.067 & 0.947\end{array}$

$\begin{array}{lllll}0.717 & 0.466 & 1.101 & -1.521 & 0.128\end{array}$

$\begin{array}{lllll}0.895 & 0.562 & 1.425 & -0.468 & 0.640\end{array}$

$\begin{array}{lllll}1.002 & 0.746 & 1.347 & 0.014 & 0.989\end{array}$

$\begin{array}{lllll}0.811 & 0.479 & 1.371 & -0.782 & 0.434\end{array}$

$\begin{array}{lllll}0.820 & 0.519 & 1.295 & -0.852 & 0.394\end{array}$

$\begin{array}{lllll}1.343 & 1.069 & 1.687 & 2.531 & 0.011\end{array}$

$\begin{array}{lllll}0.965 & 0.849 & 1.097 & -0.548 & 0.584\end{array}$

$\begin{array}{lllll}1.050 & 0.687 & 1.607 & 0.227 & 0.820\end{array}$

$\begin{array}{lllll}1.774 & 0.805 & 3.907 & 1.423 & 0.155\end{array}$

$\begin{array}{lllll}1.591 & 1.057 & 2.395 & 2.227 & 0.026\end{array}$

$\begin{array}{lllll}1.063 & 0.770 & 1.467 & 0.372 & 0.710\end{array}$

$\begin{array}{lllll}0.817 & 0.519 & 1.288 & -0.869 & 0.385\end{array}$

$\begin{array}{lllll}1.376 & 1.124 & 1.686 & 3.085 & 0.002\end{array}$

$\begin{array}{llll}0.988 & 0.758 & 1.289 & -0.086\end{array}$

$\begin{array}{lllll}1.364 & 0.828 & 2.247 & 1.218 & 0.223\end{array}$

$\begin{array}{lllll}1.065 & 0.842 & 1.347 & 0.526 & 0.599\end{array}$

$\begin{array}{lllll}1.220 & 0.851 & 1.759 & 1.084 & 0.278\end{array}$

$\begin{array}{lllll}0.882 & 0.694 & 1.120 & -1.032 & 0.302\end{array}$

$\begin{array}{lllll}0.364 & 0.021 & 6.428 & -0.689 & 0.491\end{array}$

$\begin{array}{lllll}0.448 & 0.025 & 7.900 & -0.548 & 0.583\end{array}$

$\begin{array}{llll}1.122 & 0.403 & 3.123 & 0.220\end{array}$

$\begin{array}{lllll}1.724 & 0.790 & 3.766 & 1.367 & 0.172\end{array}$

$\begin{array}{lllll}1.111 & 0.735 & 1.678 & 0.500 & 0.617\end{array}$

$\begin{array}{lllll}1.067 & 1.002 & 1.136 & 2.024 & 0.043\end{array}$
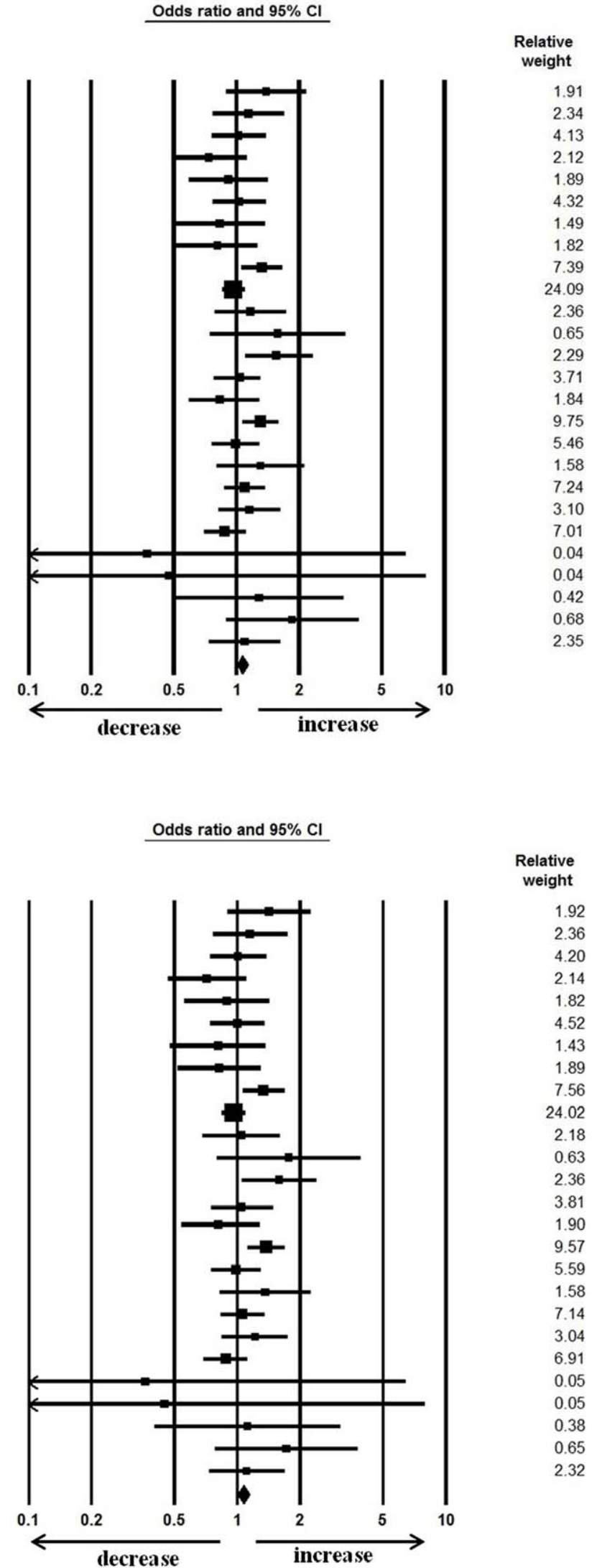
Figure 1. Forest plot of overall cancer risk associated with $+331 \mathrm{G} / \mathrm{A}$ PgR polymorphism. The squares and horizontal lines correspond to the study-specific OR and $95 \% \mathrm{Cl}$. The area of the squares reflects the weight of the respective study. The diamond represents the pooled OR and $95 \% \mathrm{Cl}$. Forest plots evaluating the association of overall allele (I), and dominant (II) genetic model with cancer risk are presented. Breast cancer, endometrial cancer and ovarian cancer denoted as $a, b$, and $c$ respectively.

doi:10.1371/journal.pone.0053308.g001

\section{Supporting Information}

\section{Ghecklist S1 PRISMA 2009 checklist. (DOC)}

\section{Acknowledgments}

We thank KWB health communications, Inc. for editing the manuscript.

\section{References}

1. Pharoah PD, Dunning AM, Ponder BA, Easton DF (2004) Association studies for finding cancer-susceptibility genetic variants. Nat Rev Cancer 4: 850-860.

2. Migliore L, Coppede F (2002) Genetic and environmental factors in cancer and neurodegenerative diseases. Mutat Res 512: 135-153.

3. ACS (2012) Cancer Facts \& Figures 2012. Atlanta: American Cancer Society.

4. Cheon YP, Li Q, Xu X, DeMayo FJ, Bagchi IC, et al. (2002) A genomic approach to identify novel progesterone receptor regulated pathways in the uterus during implantation. Mol Endocrinol 16: 2853-2871.

5. Anderson E (2002) The role of oestrogen and progesterone receptors in human mammary development and tumorigenesis. Breast Cancer Res 4: 197-201.

6. Kariagina A, Aupperlee MD, Haslam SZ (2008) Progesterone receptor isoform functions in normal breast development and breast cancer. Crit Rev Eukaryot Gene Expr 18: 11-33.

7. Ismail PM, Amato P, Soyal SM, DeMayo FJ, Conneely OM, et al. (2003) Progesterone involvement in breast development and tumorigenesis-as revealed by progesterone receptor "knockout" and "knockin" mouse models. Steroids 68 : 779-787.

8. Mote PA, Graham JD, Clarke CL (2007) Progesterone receptor isoforms in normal and malignant breast. Ernst Schering Found Symp Proc: 77-107.

9. Sartorius CA, Groshong SD, Miller LA, Powell RL, Tung L, et al. (1994) New T47D breast cancer cell lines for the independent study of progesterone B- and A-receptors: only antiprogestin-occupied B-receptors are switched to transcriptional agonists by cAMP. Cancer Res 54: 3868-3877.

10. Terry KL, De Vivo I, Titus-Ernstoff L, Sluss PM, Cramer DW (2005) Genetic variation in the progesterone receptor gene and ovarian cancer risk. Am J Epidemiol 161: 442-451.

11. Huggins GS, Wong JY, Hankinson SE, De Vivo I (2006) GATA5 activation of the progesterone receptor gene promoter in breast cancer cells is influenced by the +331G/A polymorphism. Cancer Res 66: 1384-1390.

12. Egger M, Davey SG, Schneider M, Minder C (1997) Bias in meta-analysis detected by a simple, graphical test. BMJ 315:629-34

13. Mantel N, Haenszel W (1959) Statistical aspects of the analysis of data from retrospective studies of disease. J Natl Cancer Inst 22: 719-748.

14. DerSimonian R, Laird N (1986) Meta-analysis in clinical trials. Control Clin Trials 7: 177-188.

15. Higgins JP, Thompson SG, Deeks JJ, Altman DG (2003) Measuring inconsistency in meta-analyses. BMJ 327: 557-560.

16. Feigelson HS, Rodriguez C, Jacobs EJ, Diver WR, Thun MJ, et al. (2004) No association between the progesterone receptor gene $+331 \mathrm{G} / \mathrm{A}$ polymorphism and breast cancer. Cancer Epidemiol Biomarkers Prev 13: 1084-1085.

17. Pearce CL, Hirschhorn JN, Wu AH, Burtt NP, Stram DO, et al. (2005) Clarifying the PROGINS allele association in ovarian and breast cancer risk: a haplotype-based analysis. J Natl Cancer Inst 97: 51-59.

18. Fernandez LP, Milne RL, Barroso E, Cuadros M, Arias JI, et al. (2006) Estrogen and progesterone receptor gene polymorphisms and sporadic breast cancer risk: a Spanish case-control study. Int J Cancer 119: 467-471.

19. Pooley KA, Healey CS, Smith PL, Pharoah PD, Thompson D, et al. (2006) Association of the progesterone receptor gene with breast cancer risk: a singlenucleotide polymorphism tagging approach. Cancer Epidemiol Biomarkers Prev 15: 675-682.

20. Romano A, Lindsey PJ, Fischer DG, Delvoux B, Paulussen AD, et al. (2006) Two functionally relevant polymorphisms in the human progesterone receptor gene (+331 G/A and progins) and the predisposition for breast and/or ovarian cancer. Gynecol Oncol 101: 287-295.

21. Johnatty SE, Spurdle AB, Beesley J, Chen X, Hopper JL, et al. (2008) Progesterone receptor polymorphisms and risk of breast cancer: results from two Australian breast cancer studies. Breast Cancer Res Treat 109: 91-99.

22. Diergaarde B, Potter JD, Jupe ER, Manjeshwar S, Shimasaki CD, et al. (2008) Polymorphisms in genes involved in sex hormone metabolism, estrogen plus progestin hormone therapy use, and risk of postmenopausal breast cancer. Cancer Epidemiol Biomarkers Prev 17: 1751-1759.

\section{Author Contributions}

Performed the inclusion of database searches, reviewed and selected eligible literature: SC DRM. Conceived and designed the experiments: SKM SG. Performed the experiments: SC AKP DRM. Analyzed the data: SKM SC AKP. Contributed reagents/materials/analysis tools: SKM. Wrote the paper: SKM SC.

23. Kotsopoulos J, Tworoger SS, De Vivo I, Hankinson SE, Hunter DJ, et al. (2009) $+331 \mathrm{G} / \mathrm{A}$ variant in the progesterone receptor gene, postmenopausal hormone use and risk of breast cancer. Int J Cancer 125: 1685-1691.

24. Reding KW, Li CI, Weiss NS, Chen C, Carlson CS, et al. (2009) Genetic variation in the progesterone receptor and metabolism pathways and hormone therapy in relation to breast cancer risk. Am J Epidemiol 170: 1241-1249.

25. Berchuck A, Schildkraut JM, Wenham RM, Calingaert B, Ali S, et al. (2004) Progesterone receptor promoter $+331 \mathrm{~A}$ polymorphism is associated with a reduced risk of endometrioid and clear cell ovarian cancers. Cancer Epidemiol Biomarkers Prev 13: 2141-2147.

26. Risch HA, Bale AE, Beck PA, Zheng W (2006) PGR +331 A/G and increased risk of epithelial ovarian cancer. Cancer Epidemiol Biomarkers Prev 15: 17381741 .

27. Ludwig AH, Murawska M, Panek G, Timorek A, Kupryjanczyk J (2009) Androgen, progesterone, and FSH receptor polymorphisms in ovarian cancer risk and outcome. Endocr Relat Cancer 16: 1005-1016.

28. De Vivo I, Huggins GS, Hankinson SE, Lescault PJ, Boezen M, et al. (2002) A functional polymorphism in the promoter of the progesterone receptor gene associated with endometrial cancer risk. Proc Natl Acad Sci U S A 99: 1226312268.

29. O’Mara TA, Fahey P, Ferguson K, Marquart L, Lambrechts D, et al. (2011) Progesterone receptor gene variants and risk of endometrial cancer. Carcinogenesis 32 : $331-335$

30. Lee E, Hsu C, Haiman CA, Razavi P, Horn-Ross PL, et al. (2010) Genetic variation in the progesterone receptor gene and risk of endometrial cancer: a haplotype-based approach. Carcinogenesis 31: 1392-1399.

31. Conneely OM, Maxwell BL, Toft DO, Schrader WT, O'Malley BW (1987) The $\mathrm{A}$ and $\mathrm{B}$ forms of the chicken progesterone receptor arise by alternate initiation of translation of a unique mRNA. Biochem Biophys Res Commun 149: 493501.

32. Kastner P, Krust A, Turcotte B, Stropp U, Tora L, et al. (1990) Two distinct estrogen-regulated promoters generate transcripts encoding the two functionally different human progesterone receptor forms A and B. EMBO J 9: 1603-1614.

33. Mote PA, Balleine RL, McGowan EM, Clarke CL (2000) Heterogeneity of progesterone receptors $\mathrm{A}$ and $\mathrm{B}$ expression in human endometrial glands and stroma. Hum Reprod 15 Suppl 3: 48-56.

34. Li AJ, Baldwin RL, Karlan BY (2003) Estrogen and progesterone receptor subtype expression in normal and malignant ovarian epithelial cell cultures. Am J Obstet Gynecol 189:22-27.

35. Ismail PM, DeMayo FJ, Amato P, Lydon JP (2004) Progesterone induction of calcitonin expression in the murine mammary gland. J Endocrinol 180: 287295.

36. Huggins GS, Wong JY, Hankinson SE, De Vivo I (2006) GATA5 activation of the progesterone receptor gene promoter in breast cancer cells is influenced by the +331G/A polymorphism. Cancer Res 66: 1384-1390

37. De Vivo I, Huggins GS, Hankinson SE, Lescault PJ, Boezen M, et al. (2002) A functional polymorphism in the promoter of the progesterone receptor gene associated with endometrial cancer risk. Proc Natl Acad Sci U S A 99: 1226312268.

38. Yang DS, Sung HJ, Woo OH, Park KH, Woo SU, et al. (2010) Association of a progesterone receptor gene $+331 \mathrm{G} / \mathrm{A}$ polymorphism with breast cancer risk: a meta-analysis. Cancer Genet Cytogenet Vol: 196: 2, 194-197.

39. Yu KD, Chen AX, Shao ZM (2010) No association between a progesterone receptor gene promoter polymorphism $(+331 \mathrm{G}>\mathrm{A})$ and breast cancer risk in Caucasian women: evidence from a literature-based meta-analysis. Breast Cancer Res Treat 122: 853-858.

40. Douglas FE, Rosalind AE (2008) Genome-wide association studies in cancer. Hum. Mol. Genet 17: 109-115.

41. Rockwell LC, Rowe EJ, Arnson K, Jackson F, Froment A, et al. (2012) Worldwide distribution of allelic variation at the progesterone receptor locus and the incidence of female reproductive cancers. American Journal of Human Biology Vol. 24:1:42-51. 
42. Jallow M, Teo YY, Small KS, Rockett KA, Deloukas P, et al (2009) Genomewide and fine-resolution association analysis of malaria in West Africa. Nature Genetics 41:657-65.

43. Panda AK, Panda SK, Sahu AN, Tripathy R, Ravindran B, et al. (2011) Association of ABO blood group with severe falciparum malaria in adults: case control study and meta-analysis. Malaria Journal 10:309.

44. Fuu-Jen T, Chi-Fan Yang, Ching-Chu C, Lee-Ming C, Chieh-Hsiang Lu, et al. (2010) A Genome-Wide Association Study Identifies Susceptibility Variants for Type 2 Diabetes in Han Chinese. Plos Genetics10.1371/journal.pgen.1000847.

45. Panda AK, Parida JR, Tripathy R, Pattanaik SS, Ravindran B, et al. (2012) Low producer MBL genotypes are associated with susceptibility to systemic lupus erythematosus in Odisha, India. Human Immunology 10.1016/j.humimm.

46. Amos W, Driscoll E, Hoffman JI (2010) Candidate genes versus genome-wide associations: which are better for detecting genetic susceptibility to infectious disease? $10.1098 / \mathrm{rspb} .2010 .1920$.

47. Ismail PM, DeMayo FJ, Amato P, Lydon JP (2004) Progesterone induction of calcitonin expression in the murine mammary gland. J Endocrinol 180: 287295.

48. Lydon JP, DeMayo FJ, Funk CR, Mani SK, Hughes AR, et al. (1995) Mice lacking progesterone receptor exhibit pleiotropic reproductive abnormalities. Genes Dev 9: 2266-2278.
49. Vegeto E, Shahbaz MM, Wen DX, Goldman ME, O’Malley BW, et al. (1993) Human progesterone receptor A form is a cell- and promoter-specific repressor of human progesterone receptor B function. Molecular Endocrinology Vol: 7:10:1244-1255.

50. Giangrande PH, Kimbrel EA, Edwards DP, McDonnell DP (2000) The opposing transcriptional activities of the two isoforms of the human progesterone receptor are due to differential cofactor binding. Mol Cell Biol 20: 3102-3115.

51. Ito K, Utsunomiya H, Yaegashi N, Sasano H (2007) Biological roles of estrogen and progesterone in human endometrial carcinoma - new developments in potential endocrine therapy for endometrial cancer. Endocrine Journal 54: 667679.

52. Wallace AE, Gibson DA, Saunders PTK, Jabbour HN (2010) Inflammatory events in endometrial adenocarcinoma. Journal of Endocrinology 206: 141-157.

53. Doll A, Abal M, Rigau M, Monge M, Gonzalez M, et al. (2008) Novel molecular profiles of endometrial cancer - new light through old windows. Journal of Steroid Biochemistry and Molecular Biology 108: 221-229.

54. Pijnenborg JMA, Romano A, Dam-de Veen GC, Dunselman GAJ, Fischer D-C, et al. (2005) Aberrations in the progesterone receptor gene and the risk of recurrent endometrial carcinoma. The Journal of Pathology Vol. 205: 5:597605 . 